\title{
Product Quality Perception and Customer Loyalty
}

\author{
Anthony Nwachukwu \\ National Broadcasting Corporation, \\ Owerri, Nigeria \\ Virginia Benson-Eluwa \\ Department of Marketing, \\ Abia State University, Utruru, Nigeria \\ Ikechukwu. Ejirihugha Valentine \\ Department of Marketing, \\ Akanu Ibiam Federal Polytechnic, Unwana, Nigeria \\ Obi Keneth \\ Department of Marketing, \\ Imo State Polytechnic, Umuagwo, Nigeria
}

\begin{abstract}
This paper conceptualizes product quality as brand performance, reliability and innovativeness. Using the responses of 200 buyers of Detoll, the study affirms with the aid of t-test in SPSS that these dimensions of product quality affect customer loyalty significantly.
\end{abstract}

Key Words: Product, Quality, Customer loyalty.

\section{INTRODUCTION}

Consumers purchase a product or service to satisfy their recognized need (palmer, 2001). The choice of the product depends on the perception of the consumer about the product quality capable of satisfying the need. According to Agu (2014), the product occupies a central position in the overall activities of the organization. A company's products define its business and all marketing activities resolve around the product. Kotler and Keller (2007) see a product as the key element in the marketing offering. Getting the quality product requires an understanding of what the consumer expects. This means demands that firms seek out means of studying and knowing the perception of their customers on their brands, especially, the quality dimension.

According to Perrault et al (1997) many business managers get wrapped up in the technical details involved in producing a product, but most customers or consumers think about product in terms of quality and total satisfaction it provides. In this direction the only way for a firm's product to survive in the market is to design a product with a variable that consumer use to determine product quality. It is also important for business to look for a way of gaining and sustaining brand loyalty by building consumer trust. Organizations have realized that when customers are loyal to their brands, it provides the organization with steady form of income which in turns increases profit.

Many factors may draw a buyer to a particular brand including the way the buyer perceives that price, brand quality, situational constraints, a lack of alternatives or simply because the customer finds it convenient among others (Leu et al, 2006). However, the quality of a product affects all other areas that may service as unique selling proposition (Agu, 2014). This 
implies that a poor quality product will fail in the market not minding its efficient price, distribution and promotional strategies. This work focused on Dettol Company to ascertain the effect of their customers' perception of the product quality on loyalty intention. Brand quality was conceptualized using brand performance, brand reliability and brand innovativeness, while the five Rs model by Agu and Okpara (2015) was used to measure customer loyalty.

\section{The Problem}

Dettol Nigeria Company is known for the good quality of their brands such as soap and disinfectants and other deodorants. The firm however is not without challenges. The level of competition in the industry is very high in today. Every organization is therefore determined to differentiate their brand and service offering compared to their competitors. Again, since many other relatively good quality alternatives are available, even at lower rates, the customer loyalty is in doubt, especially in the period of economic recovery. Since the firm lays emphasis on its quality, there is the need to know whether Nigerian buyers still perceive the quality as a major driver of their loyalty to Detoll brands.

\section{Objectives}

The main purpose of the study is to find out the effect of product quality perception on brand loyalty. Other specific objectives are therefore as follows:

1. To determine whether brand performance affects customer loyalty.

2. To assess the extent to which brand reliability affects customer loyalty

3. To determine whether brand innovativeness affects customer loyal

\section{Hypotheses}

The hypotheses were formulated to guide this study:

Ho 1. Brand performance does not affect customers' loyalty significantly.

Ho 2. Brand reliability does not affect customers' loyalty significantly.

Ho 3. Brand innovativeness does not affect customers' loyalty.

\section{CONCEPTUAL REVIEW: THE PRODUCT}

The product occupies a central position in the overall activities of the organization. Marketing activities production activities finance and accounting functions, personnel functions etc are of no value if the organization does not have any product to offer to the market (Agu, 2014). In fact, an organization has no reason being in business if it has no product to offer. The failure of a company's product in the market place will result in the failure of production, marketing, finance, accounting, personnel and every other managerial function in the organization.

To kotler (1999), a product is anything that can be offered to a market for attention, acquisition, use or consumption, and which might satisfy a want or need. okpara (2014) sees it is an offer with its accompanying attributes, to a target market, for acceptance and ultimate satisfaction of need. (Of time, place, form, ownership or possession) offered to a market for acquisition, use or consumption.

From these definitions, the following characteristics of a product, according to Agu (2014) could be observed.

- A product must possess utility, which is the ability to satisfy a need or want.

- A product is more than the physical object as it includes such elements as quality, warranty, color, delivery, installation, credit, manufacturer's reputation, price, after sales service, information retailer's attitude etc. 
- A product can be in the forms of goods, services, personalities, place, ideas, organization events etc.

- A product is an offering to a market.

- It can be durable, non-durable, tangible, and intangible, for immediate personal use or for business or commercial use.

- A product is the key element among the basic marketing mix elements. Others are price, place, and promotion.

- A product has a life cycle like human being.

- Aging product can become "born again" through innovations.

- A product is highly affected by changes in market (consumers) taste and preferences.

- A product must have a name.

\section{Product Quality}

Juran (2018) coined a short definition of quality as product's fitness for use. Product quality means to incorporate features that have a capacity to meet consumer needs (want) and gives customer satisfaction by improving product (goods) and making them free from any deficiencies or defects. Product quality mainly depends on the important factors like.

1. The types of raw material used for making a product.

2. How well are various production- technologies implemented?

3. Skill and experience of manpower that is involved in the production process.

4. Availability of production-related overhead like power and water supply, transport, etc.

Product quality has two main characteristics viz. measures and attributes. Measures characteristics include features like shape, size, color, appearance, height, weight, thickness, volume etc of a product. While the attributes includes check and control defectives-piece per batch, defect per item etc. Based on this classification, we can divide products into good and bad. So, product quality refers to the total of the goodness of a product. Quality of design: the product must be designed as per the consumers' needs and high-quality standards.

1. Quality conformance: the finished product must conform (match) to the product design specifications.

2. Reliability: the product must be reliable or dependable. They must not easily breakdown or become non-functional. They must also require frequent repair. They must remain operational for a satisfactory longer time to be called as a reliable one.

3. Proper storage: the finished product must be packed and stored properly. Its quality must be maintained until its expiry date.

4. Safety: the finished product must be safe for use and/or handling. It must not harm consumers any way.

According to Iwuchukwu (2001:120) there are several factors that determine the right quality for a product or service. These include

- Price: since the competitive selling price of the product in the material or component is to be incorporated will determine the price paid for the bought out items.

- Specification of customer or those laid down statutory and similar organizations.

- Life of the product: in which purchased items will be used for instance, if the expected life of the final product is only two years there is little point in incorporating components with life of four years where cheaper alternative available.

- Reliability referred quality is determined by balancing technical consideration such as fitness for use, performance, safety and reliability against economic factors including price and availability. 
In expressing the important of quality to a product, iwuchukwu (2001:20) emphasized that the responsibility of consumers to the right quality has been enhanced developed such as.

a. An aggressive competitive cost and profit consciousness environment which makes an increasingly necessary to apply sound quality principles to management in all works of life and at all levels

b. The development of national and international standard specification intended to provide a world side base from which sound quality management procedures can be involved applicable to all type of product manufacture.

c. The emergence of strategies such as just-in-time purchasing the success of which depends heavily on the quality of buyer to obtain consistently high quality products (Onah and Thomas, 2004; Okpara, 2012).

\section{THEORETICAL FRAMEWORK}

The study is based on the self perception theory which attempts to explain how individual develop an understanding of the motivations behind their own behavior. Self perception by customer relate to value and motivations that drive buying behavior- which is also an important aspect of consumer perception theory. Self-perception theory (SPT) is an account of attitude formation developed by psychologist Daryl Bem. It asserts that people develop their attitude (when there is no previous attitude due to lack of experience, etc and the emotional response is ambiguous) by observing their own behavior and concluding what attitudes must have caused it. The theory counterintuitive in nature, as the conventional wisdom is that attitude determines behaviors, furthermore, the theory suggests that people induce attitude without accessing internal cognition and mood states. The consumer interprets his/her overt behaviors rationally in the same way they attempt to explain others' behaviors. Thus, a consumer's perception of the quality of a product, for instance detoll, can influence loyalty decision.

\section{Customer Loyalty}

Customer loyalty comprises both customer's attitude and behavior. Customers' attitudinal component represents notions like repurchase intention or purchasing additional products or services from the same company, willingness of recommending the company by exhibiting a resistance to switching to another competitor (Cronin and taylor ,1992, Narayandas,1996, prus and Brandt,1995), and willingness to pay a price(Zeinthaml,Berry,and Parasuraman,1996).on the other hand ,the behavioral aspect of customer loyalty represents actual repeat purchase of products or services from the company recommending the company to other and reflecting a long term choice probability for the brand (Feick,Lee and Lee 2001).

\section{Models Of Customer Loyalty}

The model of customer's loyalty (5Rs model) was developed by Agu and Okpara (2015), Agu and Okpara (2015) developed this new model of principal component (stages) of consumer loyalty with its resulting bensefits. This model known as the five Rs model of customer loyalty and the resulting benefits are shown. It proposes that there are five level of customer's loyalty (loyal customers). The Repeater; are those who are satisfied and decide to re-patronize the service provider but if the initial satisfaction is not received again, they may switch provider. Retainers; have been satisfied that even when poor service occur, they still bear with it and remain loyal to the firm. The Rebuilders; have seen themselves as stockholders in the organization that they make constructive complaints and suggestion to see that the firm remains at its best. The Reapers; are those customer who loyalty to the firm has made them beneficiaries in the organization. The firm gives them annual prizes, discounts and reduces 
penalties for failure emanating from them. For instance, transport has the Gold and Diamond customers.

\section{Empirical Review}

Based on the reference and adoption of relevant information from other related project materials, journal (published and unpublished) textbooks etc. on the study under investigation, gave a significant content or the literature review, it is expedient to summarize this under empirical study.

In the study conducted by Grace (2011), the purpose of this research was to investigate the degree of effect product quality has on brand loyalty and determine other factors that are responsible for brand loyalty especially in the Nigeria telecommunications industry. Previous research had show that product quality has an effect on brand loyalty but there is still little or no literature discussing the extent to which product quality influence brand loyalty and none of the product quality models adopted for the Nigeria market. The qualitative and quantitative research methods were used; interviews were conducted on five MTN personnel and questionnaire was distributed to 150 respondents who use MTN in the Victoria Island metropolis, lagos state. The research result showed that product quality was not the strongest factors that led to brand loyalty but market inertia and that product quality was more likely to lead to brand loyalty when customers judged the product as having very high or high quality in the Nigerian telecommunications environment. A critical study of market inertia as a factor that leads to brand loyalty is recommended.

Archana et al (2014) investigated how brand loyalty, brand image, and perceived quality affect the brand equity of banks Islam, based on the evaluation and prioritization of brand equity dimensions from the customers viewpoint. This study employed a cross-sectional design and used a self-administration questionnaire and collected data from 200 clients of bank Islam from Kclantan, Malaysia. Findings of this study noted that brand loyalty and brand image has a significant positive contribution to brand equity. Bank Islam should, therefore focus on designing products and service that benefit client more than or equal to the conventional banks, within the borderline of Islamic banking practice.

Evelyn (2013) the study is on the effect of product quality on the consumer brand loyalty: a tool for achieving customer brand loyalty in the 7up bottling company Aba was conducted to investigate the extent of relationship between product quality and consumer brand loyalty in the 7 up company. More so, to achieve the objectives of the study, a research design was used to study the company where 140 questionnaires were administered to the respondents in order to obtain first hand information. After the analysis of the data collected, the hypotheses were tested using the chi-square SPSS formula, where the decision shows when the value of \%x in SPSS is less than the alpha value of 0.05 and less than $x^{2}$ value from the tables, we therefore, reject Ho and accept Ha that product quality increases the demand of a product. Based on the findings of this study, that the quality of a product affects consumers' loyalty, the following were recommended. That for an organization to maintain consumer loyalty, product quality must be well planned and mutinously adhered due to increasing market completion in brand lines. From the recommendations, the following suggestion for further studies were made that effort should be made to study the effect of quality in other product.

Chinwendu (2017) the research revealed extensively the impact of product quality on consumer brand loyalty. The main purpose was to find out the impact of product quality on consumer brand loyalty as generated high profit to intercontinental distiller limited products in ota, Ogun state. Both primary and secondary data collection method were used in gathering 
information, books journal and past project were used. Questionnaires were administered and personal interview were conducted. The major findings were those consumers who are strictly concerned about product features. It was also find that product quality has great influence in consumer preference as promotional message with great precision to advertising brand loyalty. It was therefore recommended that quality level of the product yield great influence on consumer. It should therefore be strictly maintained and improved. They should also know every producer of products of any sort should pay great attention to most qualitative production with its ability.

\section{RESEARCH METHODOLOGY}

This research was carried out in Asaba Delta State. As a result of the nature of this study, the survey research was adopted. According to Anyanwu (2000), the survey research design is the investigation of the behavior, opinion or other manifestation of a group of people by questioning them. To achieve this, the questionnaire was utilized. Again, cross-sectional survey design which is a variant of the survey (descriptive) research design was adopted in the study since the study would be carried out at different point within a given time from a sample of elements (representatives) from the study population. As rightly observed by, Ezejelue, Ogwo and Nkamnebe (2008), a cross-sectional survey usually consists of gathering data from population of interest, measured on a number of characteristics, which are thought to be relevant to the area of research interest. The questionnaire was shared among the four (4) zones which serve as segment of the study.

The three zones are identified with the use of alphabets

Zone A - Aniocha North

Zone B - Aniocha South

Zone C - Oshimili North

Zone D - Oshimili South

Thus, the geographical scope covered Asaba, Delta state, while the subject scope covered consumer behavior and brand management. The likert scale questions of five options (strongly agree, agree, strongly disagree, disagree and undecided) were used to capture respondents views on the effect of the identified variables on their patronage behavior. Copies of the questionnaire were administered face-to-face by the researcher with the aid of thoroughly trained research assistants that drawn from students. 200 respondents were involved in the study. The collected data were analyzed using descriptive and inferential statistics. Stated hypothesis were tested using SPSS one-sample t-test

\section{RESULTS AND INTERPRETATIONS}

Of the total of 200 copies were issued 50,100, 30, and 20 to Aniocha-north, Aniocha-south, Oshimili-north, and Oshimili-south respectively, of these figures a total of $180(90 \%)$ copies were retrieved,45(90\%),95(95\%),20(67\%) and 20(100\%) respectively for Aniocha-north, Aniocha-south, Oshimili-north and Oshimili-south. Again, a total of 20 copies representing $10 \%$ were lost. 5(25\%),5(25\%) and 10(50\%) for Aniocha-north, Aniocha-south, and Oshimili-north respectively. Also a total of $160(80 \%)$ copies of the questionnaire were found useful for further analysis. The 20 copies dropped were from 20 respondents who disclosed that they are not loyal to the brand (Dettol). In all of the 160(80\%) copies used for major analysis. $40(25 \%), 90(50 \%), 14(9 \%), 16(10 \%)$ were Dettol customers who are loyal to the brand. The researchers recorded 90\% overall retrieved rate, 90\% in Aniocha-north, 95\% in Aniochasouth, $67 \%$ in Oshimili-north and $100 \%$ in Oshimili-south. It should be noted that 160 of the respondents $89 \%$ of the 180 respondent whose copies of questionnaire were retrieved. 


\section{Test of Hypothesis One}

Ho: Consumers' perception of brand performance does not affect their loyalty intention significantly.

\section{Interpretation:}

The one-sample statistics shows a mean value of 3.89 with lower and upper mean values of 3.68 and 4.09 respectively. This implies that an average respondent sampled agreed that brand perception impacts on customer loyalty.

\section{Decision:}

Given the value of t-test calculated (8.46), and P-value (Sig.2 tailed) of (.000) which are greater than t-critical (1.96) at degree of freedom (159) and alpha (.05), we therefore reject the null and accept the alternate hypothesis which implies that consumers' perception of brand performance affects their loyalty intention significantly

\section{Test Of Hypothesis Two}

Ho: Brand reliability does not affect brand loyalty significantly.

\section{Interpretation:}

The one-sample statistics shows a mean value of 4.44 with lower and upper mean values of 4.28 and 4.58 respectively. This implies that an average respondent sampled agreed that brand reliability impacts on customer loyalty.

\section{Decision:}

Given the value of t-test calculated (18.16), and P-value (Sig.2 tailed) of (.000) which are greater than t-critical (1.96) at degree of freedom (159) and alpha (.05), we therefore reject the null and accept the alternate hypothesis which brand reliability affects customer loyalty significantly.

\section{Test of Hypothesis Three}

Ho: Brand innovativeness does not affect customer loyalty significantly.

\section{Interpretation:}

The one-sample statistics shows a mean value of 4.75 with lower and upper mean values of 4.63 and 4.86 respectively. This implies that an average respondent sampled strongly agreed that brand innovativeness impacts on customer loyalty.

\section{Decision:}

Given the value of t-test calculated (27.91), and P-value (Sig.2 tailed) of (.000) which are greater than t-critical (1.96) at degree of freedom (159) and alpha (.05), we therefore reject the null and accept the alternate hypothesis which implies that Brand innovativeness affects customer loyalty significantly.

\section{FINDINGS}

The following major findings were made in the study

1. It was discovered through the study that consumer perception of brand performance affects their loyalty intention significantly. This assertion is based on the tested hypothesis and the responses on table 4.3.

2. Also, it was discovered through the study that brand reliability affects consumer loyalty significantly; it was based on the tested hypothesis and the response in table 4.3.1.

3. The study disclosed that brand innovativeness affects customer loyalty significantly, this assertion is based on the tested hypothesis and the responses on table 4.8

\section{CONCLUSION}

The emerging competition for consumer in this modern day has made firms more recognized while product quality is revolving more than ever because of change in the consumer status test and preference. This study was carried out to discover the relationship between product 
quality and consumer brand loyalty. Based on the findings of the study, it could be conducted that brand performance affect the loyalty of the consumer, that brand reliability affect the customer loyalty and also brand innovative affect their loyalty.

\section{RECOMMENDATIONS}

Based on the findings of the study, the following recommendation are hereby made

1. For an organization to maintain consumer loyalty, product quality must be well planned and mutinously adhered to increase market completion in brand lines.

2. The product manufacturer should evaluate their brand performance in order to maintain consumer loyalty.

3. Some percentage of people using dettol think that price of the product is high enough so no more rising of the prices will make them continue to buy the product.

4. Dettol product producers should consider the reasons which motivate the customers to buy their brand as they concerned with the germs issue.

5. The quality of dettol should be regularly enhanced, so as to meet particular standards.

6. There should be more innovation of brand which should be done constantly.

7. The product should always be reliable.

\section{References}

Aake, D. A.(2000), “Brand Extension, the Good, the Bad," Sloan Management Review, 3(1).

Agu, G. A. (2014).New Model of Product Centrality. Innovation and Branding Management. Owerri, Avan Global Press.

Agu, G. A. and Okpara, G. S. (2015).Comparative Customer Complaints Management Strategies in the Road Transport Sector: A Study of the Organized Road Transport Companies in Imo State, journal of Marketing Research,3 (1).

Agu, G. A. (2015). Customer Compliant Behavior in the service Industry: A Study of the customers of the organized Road Transport Firms in Imo State,' A Ph. D. Thesis, Abia State University, Nigeria

Agu, G. A., Madumere, H. I., Etuke, S. and Kalu I. N. (2015). Rating Factors Influencing Subscribers' Loyalty to GSM Network providers in South East Nigeria. Journal of Business and Value Creation, 4 (2).

Agu, G. A. and Okpara, G. S. (2015). Comparative Complaint Management Strategies in the Organized Road Transport Firms in Imo state". Journal of Marketing Research, vol. no. 1

Anyanwu, A. V. (2003), Promotional Strategy: A Schematic Approach, Owerri: Avan Global Publications.

Anyanwu, A. V. (2000) Dimensions of Marketing. Owerri: Avan Global Publications.

Anto, J. (1996). Customer Relationship Management: making hard decisions with soft numbers. Upper Saddler River, NJ: Prentice, Ltd,

Austin, C., Ezejelue, Ogwo E. Ogwu and Anayo D. Nkamnebe (2008): Basic Principles in managing Research projects, $3^{\text {rd }}$ Edition, Awka. Afritowers Limited.

Berkowitz, E. N., Kerin, R. A., Hartley, S. W. And Rudlius, W. (2000), Marketing, 6 6 Edition, Boston: Irwin MCGRAW-Hill.

Brassington F. and Pettit, S. (1997), Principle of Marketing, London: Pitman Publishing

Bruno, K., Bredable, I., Grunert, K. G.and scholars ,J .(2005).consumer perception of the quality of beef resulting from various faltering regimes . Livestock production science ,94(1/2), 83-93.

Cateora, P.R.And Graham , J.H.(2005) International marking ,12 th edition .New York : MC Graw-Hill Irwin.

Engel ,J. B, B., Kollat and R.Black well(1966), Consumer Behavior; New York: Holt.

Engel, J. B. and Blackwell R. D. (1998) Consumer Behavior; New York: Rinchar and Winston.

Ezirim, A. C. (2002), Advertising and Sale Promotion for Modern society, Owerri: Kosoko press Ltd.

Ezejelue, A.C and Ogwo, E.O (1990). Basic Principles in Management Research Project. 
Farris, Paul W. Neil T. Bendle, Philip E. Pfeiffer, David J. Reibstern(2010). Marketing Metrices: the Definition Guide to measuring marketing performance. Upper River -New Jersey: Pearson Education.

Fornell, Claes (1992),"A National Customer Satisfaction Barometer the Swedish Experience, Journal of Marketing. Giles G. B. (2010), Marketing, Great Britain: Macdonald and Evans Ltd. 1974.

Gunelius, S. (2007), “Brand curve branding and marketing”. www,http:googlesearch,com.

Iwuchukw, O. (2001): Lecture material on purchasing and supply Imo state.

Ifezue, A. U. (2014) Pinciples of maketing, Enugu: Abia Book and equipment Ltd.

Jacoby, J. and Chestruct, R. (1998) Brand Loyalty vs Repeat purchasing behaviors, Journal of Marketing Research, 10, 1-19

Kotler, P. (1999), Maketing Management prentice Hall inc. New York.

Kotler, P. and Armstrong, G. (1999) Principles of Marketing, 8 ${ }^{\text {th }}$ ed. New Jersey: Prentice Hall Inc.

Kotler, P. (2000), Marketing Management. New Jersey: Prentice Hall Inc.

Kotler, P. and Armstrong, G. (2007), Principles of Marketing New Jersey: Prentice Hall

Kotler, P. And Keller, L. K. (2007), Marketing Management South Asia: Pearson Educational.

Kotler, P. and Keller, K. (2007) Marketing Management, (13 th ed.) New Jersey: Prentice Hall.

Lau, M. M., Chang. M. S., Moon, K. and Leu, W. S. (2006) the Brand Loyalty of Sport wear in Hong Kong, Journal of Textile and Apparel Technology and Management, 5, 1-13.

Lucy, T. (2014) Quantitative Techniques: and institution manual (3 ${ }^{\text {rd }}$ London: DP publication).

McCarthy, E. J. (2013), Basic Marketing 10th Edition, Homewood, Illinois: Rechard, D. Irwin, inc.

Nwankwo, G. O. (1991), Business Management Principle and practice.

Obiesie, M. C. (2003), Marketing Management: A Theoretical and Practical Approach, Enugu: John Jacobs publishers, Ltd.

Ogbuji, C. N. (2013), Marketing Research, African Entrepreneurship and Leadership Intiative. Enugu: through communication Publisher.

Ogbuji, C. N. (2008), "Branding: A Strategic Marketing tools in a Competitive Environment” in ogbuji, C. N. edited, Marketing in Contemporary Nigeria, Owerri: Stramark communications consult.

Okpara, G. S. (2012). Contemporary Marketing: Topical and Tropicalized.

Oliver, R. L.(1997), Satisfaction: A Behavioral Perspective on the consumer. McGraw-Hill Companies Inc. New York.

Oliver, R. L. (1999) “Whence Consumer Loyalty” Journal of Marketing vol.63. Special issue, pp. 33-44

Onah, J. O. and Thomas, M. J. (2004), Marketing Management: Strategies and Cases, Enugu: Institution for Development studies.

Stanton, W. J. (1981), Fundamentals of Marketing, Japan: McGraw-Hill Inc.

Willians, G. N. (1978). Consumer Behavior. Houghton: Mifflin Company.

Wind, Y. (1970), Industrial Source Loyalty Journal of Marketing Research,7(November), 450-457 